\title{
We Made That Call
}

Author(s):

Ellen Zhang, BA ${ }^{1}$

\section{Corresponding Author:}

Ellen Zhang

ellen_zhang@hms.harvard.edu

Affiliation Information for All Authors: 1. Harvard Medical School, Boston, MA

Neurology® Published Ahead of Print articles have been peer reviewed and accepted for publication. This manuscript will be published in its final form after copyediting, page composition, and review of proofs. Errors that could affect the content may be corrected during these processes. 
Contributions:

Ellen Zhang: Drafting/revision of the manuscript for content, including medical writing for content

Number of characters in title: 17

Abstract Word count:

Word count of main text: 118

References: 0

Figures: 0

Tables: 0

Search Terms: [ 2 ] All Cerebrovascular disease/Stroke

Study Funding: The authors report no targeted funding

Disclosures: E. Zhang serves as an advisory board member for National Alzheimer's Buddies.

\author{
We made that call \\ on the CT scan as \\ blood spilled over \\ your ventricles \\ to the surgeons \\ regarding emergent \\ interventions \\ before we rushed \\ you out of one room \\ into another \\ to pharmacologists \\ as lines flowed \\ with medications \\ so easily we made \\ those calls but \\ in the last one \\ I still hear the break \\ in your wife's voice \\ when she asks \\ if she will ever
}


be able to see

you again

in those moments

it is hard to tell her

that I have seen

and cared for

hundreds of

stroke patients

when outcomes differ

and none of them

are her husband

yet I start the

drive home

dial her number

talk for miles and

miles on end

knowing that

minutes can

determine

lifetimes 


\section{Neurology}

We Made That Call

Ellen Zhang

Neurology published online February 10, 2022

DOI 10.1212/WNL.0000000000200184

\section{This information is current as of February 10, 2022}

Updated Information \&

Services

Subspecialty Collections

Permissions \& Licensing

Reprints including high resolution figures, can be found at:

http://n.neurology.org/content/early/2022/02/10/WNL.0000000000200184. citation.full

This article, along with others on similar topics, appears in the following collection(s):

All Cerebrovascular disease/Stroke

http://n.neurology.org/cgi/collection/all_cerebrovascular_disease_stroke

Information about reproducing this article in parts (figures,tables) or in its entirety can be found online at:

http://www.neurology.org/about/about_the_journal\#permissions

Information about ordering reprints can be found online:

http://n.neurology.org/subscribers/advertise

Neurology $\AA^{\circledR}$ is the official journal of the American Academy of Neurology. Published continuously since 1951, it is now a weekly with 48 issues per year. Copyright (C) 2022 American Academy of Neurology. All rights reserved. Print ISSN: 0028-3878. Online ISSN: 1526-632X.

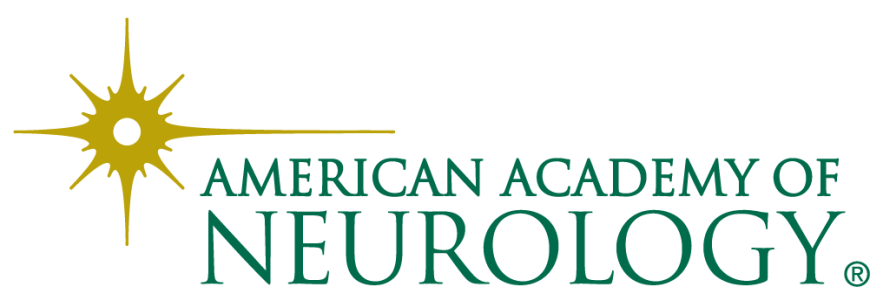

